\title{
Urea decomposition by bacteria in the Southern California Bight and its implications for the mesopelagic nitrogen cycle
}

\author{
Byung C. Cho*, Farooq Azam \\ Marine Biology Research Division, Scripps Institution of Oceanography, UCSD, La Jolla, California 92093-0202, USA
}

\begin{abstract}
We studied urea decomposition in depth profiles at stations in the Southern California Bight. Urea decomposition was measured by adding ${ }^{14} \mathrm{C}$ urea as a tracer. In situ urea concentration was measured by the urease method; we, therefore, studied the decomposition of only the urease-sensitive fraction of the urea pool. In the mesopelagic zone the decomposition of urea, which was mainly due to the bacterial size-fraction, was equivalent to $78 \pm 35 \%$ of sinking particulate nitrogen $(\mathrm{N}$ ) flux and $41 \pm 20 \%(n=4)$ of the new production and generally exceeded $N$ demand for heterotrophic bacterial production. Urea decomposition was intense in the 100 to $200 \mathrm{~m}$ depth interval where earlier studies found high nitrification rates. Our results suggest that a substantial fraction of sinking $\mathrm{N}$ flux may follow the pathway: sinking- $N \rightarrow$ urea $\rightarrow$ ammonium $\rightarrow$ nitrate rather than sinking- $N \rightarrow$ ammonium $\rightarrow$ nitrate. The significance of $\mathrm{N}$ flux via urea and its implications for bacterial production and carbonnitrogen coupling in the mesopelagial need to be considered in the oceanic biogeochemical models.
\end{abstract}

KEY WORDS: Urea decomposition - Bacteria - Mesopelagic zone $\cdot$ Nitrogen cycle

\section{INTRODUCTION}

Urea is a significant component of the biologically labile fraction of dissolved organic nitrogen in the ocean, and therefore, it is important to know the dynamics of urea pools in order to understand the oceanic nitrogen cycle (McCarthy 1980, Harrison et al. 1985, Turley 1985, Williams 1986, Hansell \& Goering 1989). Present knowledge about the urea cycle is largely limited to the euphotic zone where the existing paradigm is that urea is mainly produced by animals (McCarthy \& Kamykowski 1972, McCarthy \& Whitledge 1972, Eppley et al. 1973) and utilized by phytoplankton (Remsen et al. 1974, Mitamura \& Saijo 1975, McCarthy 1980, Harrison et al. 1985, Price et al. 1985, Turley 1985); bacteria do not play a significant role in urea decomposition in the euphotic zone (Remsen et al. 1974, Turley 1985). Whether bacteria are important in

\footnotetext{
- Present address: Department of Oceanography, Seoul National University, Kwan-Ak Gu, Shin-Lim Dong San 56-1, Seoul, Korea 151-742
}

urea decomposition in the mesopelagial has remained unstudied despite the occurrence of large pools (usually 0.1 to $1 \mu \mathrm{M}$ ) of urea there (Remsen 1971, Mezykowski 1982, Turley 1985, Sapozhnikov \& Propp 1988). Concentrations of urea greater than $1 \mu \mathrm{M}$ have often been found below the euphotic zone (Remsen 1971, Turley 1985, Sapozhnikov \& Propp 1988).

Bacteria in the ocean's mesopelagial dominate the decomposition of sinking organic carbon (Cho \& Azam 1988, Simon et al. 1992), and further, bacterial isolates from the ocean's interior are commonly ureolytic (Taga 1972), suggesting that bacteria may play a hitherto unrecognized role in urea dynamics below the euphotic zone. Since sinking flux into the aphotic zone is the major source of energy and material there and the $\mathrm{C} / \mathrm{N}$ ratio of sinking particles increases with depth (Fowler \& Knauer 1986), bacteria in the mesopelagial might be more $\mathrm{N}$-limited than bacteria in the euphotic zone. N-limited bacteria are known to decompose urea rapidly in seawater culture (Cho 1988).

The goal of this study was to determine whether bacteria in the mesopelagic zone decompose urea and 
whether bacterial decomposition of urea is rapid enough to comprise a process of significant magnitude in the mesopelagic $\mathrm{N}$ cycle in the ocean.

\section{MATERIALS AND METHODS}

During 2 cruises in the Southern California Bight, including stations in the Santa Monica Basin $\left(33^{\circ} 45.5^{\prime} \mathrm{N}\right.$, $118^{\circ} 47.6^{\prime} \mathrm{W}$ ), we sampled seawater in three $500-800 \mathrm{~m}$ and two $200 \mathrm{~m}$ deep profiles. We used seawater from the same Niskin bottle for determining bacterial abundance, concentration of urea and urea decomposition using ${ }^{14} \mathrm{C}$ urea as tracer in $183 \mu \mathrm{m}, 1.0 \mu \mathrm{m}$ or $0.8 \mu \mathrm{m}$ filtrates.

Study area and sample collection. Two cruises were made in 1985 and 1988 in the Bight (Stn 205,33 $17.3^{\prime} \mathrm{N}$,

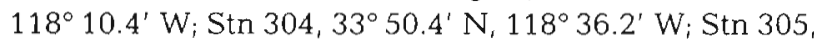
$33^{\circ} 45.5^{\prime} N, 118^{\circ} 47.6^{\prime}$ W). Seawater samples in depth profiles were obtained either with Niskin bottie or a CTD-rosette. We took seawater samples in both the euphotic and aphotic zones.

Urea decomposition activity. Seawater samples were prefiltered through a $183 \mu \mathrm{m}$ Nylon mesh to remove larger zooplankton. Urea decomposition was followed with ${ }^{14} \mathrm{C}$-urea added as the tracer, essentially by the method of Rernsen et al. (1974). Briefly, 45 to $50 \mathrm{ml}$ of seawater was inoculated with $0.2 \mu \mathrm{m}$ filtersterilized ${ }^{14} \mathrm{C}$-urea (54 to $58 \mathrm{mCi} \mathrm{mmol}^{-1}$, New England Nuclear) to attain the addition of 0.25 to $0.62 \mu \mathrm{Ci}$. The added urea concentration ranged from 86.2 to $252.5 \mathrm{nM}$. For some samples (where the ambient concentration of urea was low) this addition could not be regarded as tracer (see below). Seawater samples were incubated under white fluorescent light or in the dark for 4 to $6 \mathrm{~h}$ at in situ temperature. One bottle was fixed with neutral buffered formalin (final conc. $1 \%$ ). It served as abiotic control. After incubation with ${ }^{14} \mathrm{C}$ urea, $1 \mathrm{ml}$ of $2 \mathrm{~N} \mathrm{H}_{2} \mathrm{SO}_{4}$ was added and the liberated ${ }^{14} \mathrm{CO}_{2}$ was collected and radioassayed. All measurements were done at least in duplicates. The coefficient of variation among replicates was usually $<7 \%$. The radioactivity was measured by liquid scintillation spectrometry using the external standard ratio method. Urea decomposition rates were calculated as: $(f / t) \times($ in situ urea concentration), where $f=$ fraction of the tracer ${ }^{14} \mathrm{C}$ converted to ${ }^{14} \mathrm{CO}_{2}$ and $t=$ the duration of incubation.

As stated, ${ }^{14} \mathrm{C}$-urea additions were not always low enough to be treated as a 'trace', and it is therefore necessary to address whether this could have enhanced the decomposition rates (Savidge \& Johnston 1987). We do not think that an enhancement occurred, for the following reasons. First, a time course experiment showed that the urea decomposition rate was constant for the first $6 \mathrm{~h}$ (data not shown), suggest- ing that the urea addition did not measurably alter the rate of ureolysis. Second, our protocol is not likely to have overestimated the rates; indeed, the rates may have been underestimated. As noted above, we used the ${ }^{14} \mathrm{C}$-urea hydrolysis only to calculate the pool turnover time, $f / t$. This was then multiplied by the measured in situ concentration (and not the sum of the in situ concentration and that of the added ${ }^{14} \mathrm{C}$-urea). We did this to obtain conservative estimates unbiased by the problem of increase in urea concentration due to the addition of a tracer. Further, we treated in situ urea concentrations below $30 \mathrm{nM}$ (detection limit) as zero. In these cases, the rate we report is zero rather than that which would be based on the ${ }^{14} \mathrm{C}$-urea concentration.

Other analytical methods. Urea was measured by the method of McCarthy (1970). Samples for urea measurements taken in 1985 were filtered through GF/F filters and were kept frozen $\left(-20^{\circ} \mathrm{C}\right)$ untiil andyzed. Samples in 1988 were analyzed on board after filtration. Ammonium was measured by the method of Strickland \& Parsons (1972) or Grasshoff (1976). Bacteria were enumerated by epifluorescence microscopy of acridine orange stained samples (Hobbie et al. 1977). The rate of primary production was measured concurrently by other investigators.

\section{RESULTS AND DISCUSSION}

Urea decomposition rates below the euphotic zone ranged from negligible to $23.3 \mathrm{nM} \mathrm{d}^{-1}(2.8 \pm 5.0 \mathrm{nM}$ $\mathrm{d}^{-1}, \mathrm{n}=23$; Fig. 1). Bacteria appeared to be the main decomposers of urea in the mesopelagic zone (Fig. 1). In the majority of the samples ( 5 out of 8 ) the bacteria size-fraction $(<1.0 \mu \mathrm{m}$ filtrate) was responsible for most of the urea decomposition. Particle-bound bacteria including nitrifiers (Karl et al, 1984) could have accounted for the remainder of the activity. Uniquely for a dissolved organic matter (DOM) component, urea decomposition in the euphotic zone is dominated by phytoplankton rather than by bacteria (McCarthy 1980, Harrison et al. 1985. Turley 1985); thus, in our study, the bacteria size-fraction was responsible for only a minor part of urea decomposition activity in the euphotic zone (Fig 1). In the mesopelagic zone, however, where phytoplankton biomass should be virtually absent, most activity was due to the $<1 \mu \mathrm{m}$ fraction. Some smaller protozoa may have passed into the $<1 \mu \mathrm{m}$ fraction, but the biomass of protozoa in the mesopelagic samples in our study area was $<5 \%$ of bacterial biomass (Cho 1988) and was probably insignificant in urea decomposition. Since the contribution due to particles $>183 \mu \mathrm{m}$ (generally $<10 \%$ ) was not measured in our study, we consider our estimates 
Fig. 1 (A to D) Depth profiles of urea concentration $(\bullet)$, and urea decomposition rates in $<183 \mu \mathrm{m}$ (D) and $\leq 1.0 \mu \mathrm{m}$ filtrates (D). (E to H) Depth profiles of bacterial abundance $(0)$ and per-cell urea decomposition (घ) in the Southern California Bight. Where error bars or ranges are not shown, they are smaller that the size of symbols. (A, E) Stn 305, 28 Sep 1988; (B, F) Stn 305, 29 Sep 1988 (C, G) Stn 305, 13 Oct 1985; (D, H) Stn 304,14 Oct 1985

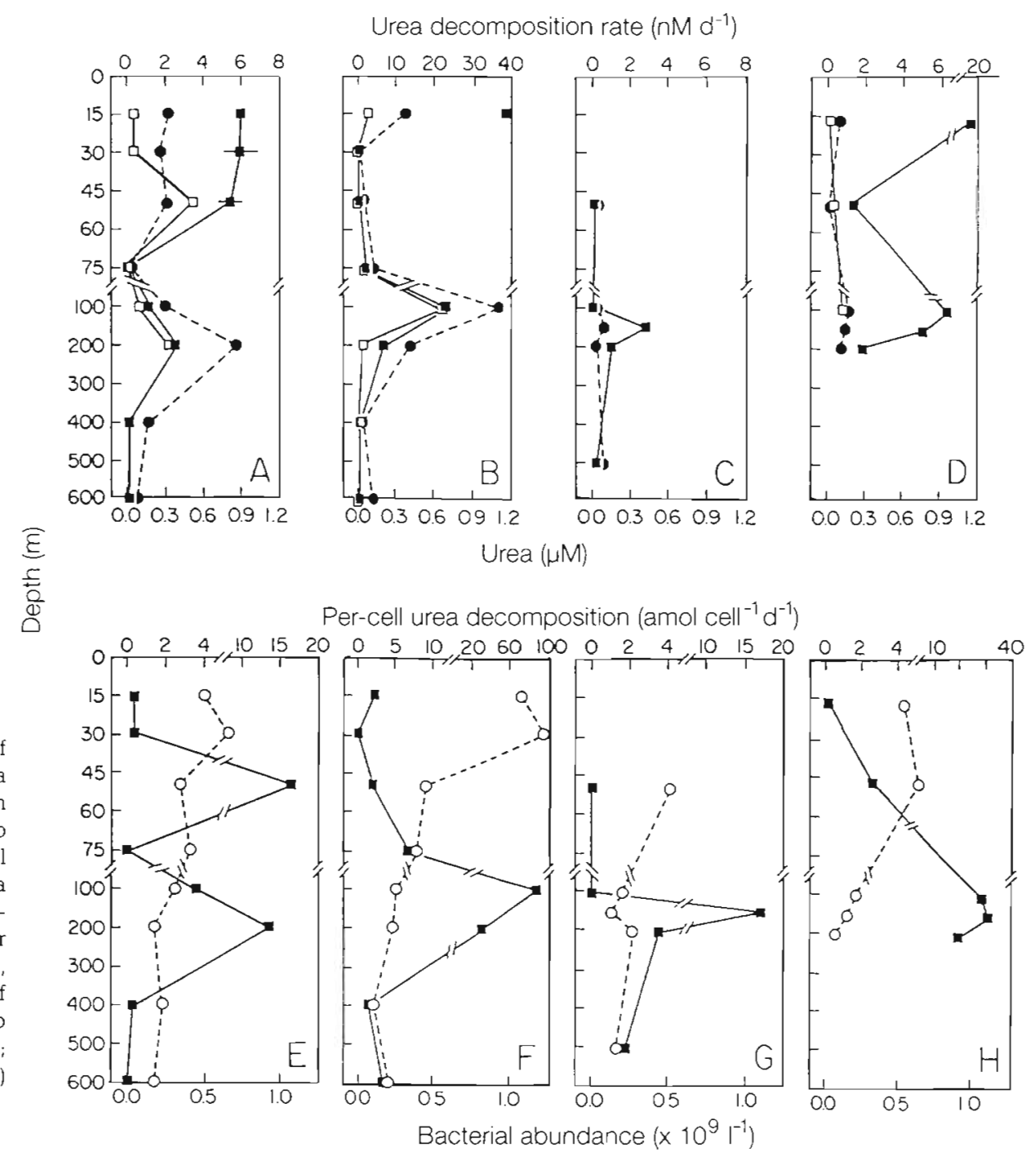

to be conservative. Size-fractionated samples (Fig. 1) indicate that most of the urea hydrolysis activity was due to bacteria operationally defined as free-living. We conclude, therefore, that most of the urea decomposition in our mesopelagic samples was due to bacteria, the majority of which were free-living. A surprising finding was that the rates of bacterial urea decomposition in the mesopelagic zone were often $1 / 3$ to $1 / 2$ of total urea decomposition rates (in the $<183 \mu \mathrm{m}$ fraction) in the euphotic zone. The high level of urease activity in the aphotic zone occurred because the per-bacterium urease activity in the aphotic zone was actually greater (up to an order of magnitude) than in the euphotic zone (Fig. 1E to $\mathrm{H}$ ). This is despite the fact that bacteria in the aphotic zone of the Bight (and in the ocean in general) grow much slower than in the euphotic zone (Cho \& Azam 1988). Thus, the slow growing mesopelagic bacterial assemblages actually express higher levels of urease than the faster growing surface assemblages, and they do not 'ignore urea' - unlike the bacteria in the euphotic zone (Turley 1985).

Urea decomposition rates consistently showed a peak in the 100 to $200 \mathrm{~m}$ depth interval in all 4 profiles. The per-cell urease activity and urea concentration also peaked in the same depth interval. It is interesting that previous work found a peak of nitrifying bacteria and ammonium oxidation in this depth interval (Ward 1987). We therefore considered that nitrifying bacteria might be intensely ureolytic and consequently responsible for significant urea hydrolysis. We examined a pure culture of the nitrifying bacterium Nitrosococcus oceanus for urea hydrolysis activity and found that it did hydrolyze urea $\left(90 \mathrm{amol}\right.$ cell ${ }^{-1} \mathrm{~d}^{-1}$; data not shown). On the basis of our per-cell hydrolysis rates for $N$. oceanus and the literature values of the abundance of nitrifying bacteria determined by immunofluores-

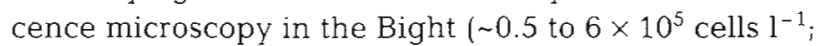
Ward 1987), we estimated whether the nitrifying bac- 
Table 1. Comparison of depth-integrated ammonium production rates via urea decomposition ( $\int \mathrm{NH}_{3} \mathrm{dz}$ ) with sinking nitrogen ( $\mathrm{N}$ ) flux into the ocean's interior ( $\left.{ }^{\mathrm{F}} \mathrm{N}\right)$ and new production (NP) in the Southern California Bight. Sinking ${ }^{\mathrm{F}} \mathrm{N}$ calculated on the basis of primary production and Pace's N flux model (1987). Primary production data from Eppley (unpubl.). NP calculated according to Eppley \& Peterson (1979) and a C/N ratio of 7 by weight for sinking materials from the euphotic zone. Nitrogen demand in bacteria calculated on the basis of earlier measurements of mesopelagic bacterial carbon production (Cho \& Azam 1988) and the $\mathrm{C} / \mathrm{N}$ ratio of 5.6 by weight (Nagata \& Watanabe 1990). Station locations: Stn $205,33^{\circ} 17.3^{\prime} \mathrm{N}, 118^{\circ} 10.4^{\prime} \mathrm{W}_{i} \mathrm{Stn} 304,33^{\circ} 50.4^{\prime} \mathrm{N}$, $118^{\circ} 36.2^{\prime} \mathrm{W}_{\mathrm{i}} \operatorname{Stn} 305,33^{\circ} 45.5^{\prime} \mathrm{N}, 118^{\circ} 47.6^{\prime} \mathrm{W}$

\begin{tabular}{|c|c|c|c|c|c|c|c|c|}
\hline $\begin{array}{l}\text { Stn } \\
\text { Date }\end{array}$ & $\begin{array}{l}\text { Depth } \\
\text { interval } \\
\text { (m) }\end{array}$ & $\begin{array}{c}\mathrm{NH}_{4}^{+} \text {production rates } \\
\text { via urea decomposition } \\
\left(\mathrm{mgN} \mathrm{m} \mathrm{m}^{-2} \mathrm{~d}^{-1}\right)\end{array}$ & 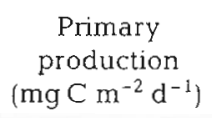 & $\begin{array}{l}\mathrm{F}_{\mathrm{N}} \\
(\mathrm{mg})\end{array}$ & $\begin{array}{c}N P \\
\left.d^{-2} d^{-1}\right)\end{array}$ & $\frac{\int \mathrm{NH}_{3} \mathrm{dz}}{\mathrm{F}_{\mathrm{N}}}$ & $\frac{\int_{0} \mathrm{NH}_{3} \mathrm{dz}}{\mathrm{NP}}$ & $\begin{array}{c}N \text {-demand } \\
\text { in bacteria } \\
\left(\mathrm{mgN} \mathrm{m}^{-2} \mathrm{~d}^{-1}\right)\end{array}$ \\
\hline $\begin{array}{l}\text { Stn } 305 \\
\text { Sep } 1988\end{array}$ & $60-500$ & $\begin{array}{c}44.5 \pm 43.9 \\
(\mathrm{n}=2)\end{array}$ & 1459 & 48.9 & 101.0 & 91 & 44 & 37.6 \\
\hline $\begin{array}{l}\text { Stn } 305 \\
\text { Oct } 1985\end{array}$ & $48-500$ & 10.6 & 531 & 19.0 & 36.7 & 56 & 29 & 37.6 \\
\hline $\begin{array}{l}\text { Stn } 304 \\
\text { Oct } 1985\end{array}$ & $49-200$ & 19.4 & 467 & 16.2 & 28.4 & 120 & 68 & 2.5 \\
\hline $\begin{array}{l}\text { Stn } 205 \\
\text { Oct } 1985\end{array}$ & $50-200$ & 10.3 & 658 & 23.3 & 45.5 & 44 & 23 & 3.9 \\
\hline
\end{tabular}

teria could have accounted for a significant fraction of the field rates of urea hydrolysis. The rate ranged fiom 5 to $54 \mathrm{pmol} \mathrm{l}^{-1} \mathrm{~d}^{-1}$, or generally 1 to 3 orders of magnitude lower than the field rates we measured. Unless the natural populations of the nitrifying bacteria had much higher per-cell urea hydrolysis activity than the cultured $N$. oceanus (for instance, if urease production is not repressed in low ammonium environments), their contribution to the measured rates of urea hydrolysis would have been negligible.

While ureolysis by nitrifiers would be a biochemical strategy for acquiring energy from ammonium, an intriguing question is why other mesopelagic bacteria should be ureolytic, i.e. whether there is an energetic advantage or nitrogen limitation. Heterotrophic bacteria in the mesopelagial might use urea (after extra-or intracellular hydrolysis to ammonium) as a nitrogen source because it is energetically more favorable to use ammonium than nitrate (even though nitrate is highly abundant below the upper mixed layer). Other potential sources of nitrogen for bacterial growth are the dissolved combined and dissolved free amino acids, but they may occur in chemical associations (condensed or complexed with carbohydrates) which render them slow-to-degrade (e.g. glucosylated proteins degrade slowly in seawater; Keil \& Kirchman 1993). Urea may represent a readily utilizable dissolved organic nitrogen (DON) source for bacterial growth in the mesopelagial (but see below regarding the possible formation of condensed urea hexamers). We estimate on the basis of earlier measurements of mesopelagic bacterial carbon production in our study area (Cho 1988, Cho \& Azam 1988) that our measured rates of urea hydrolysis could provide a large fraction of the $\mathrm{N}$ demand of bacteria and may exceed it $(297 \pm$ $334 \%$, range 28 to $776 \%$; Table 1 ). Whether urea is taken up intact by bacteria and hydrolysed intracellularly to ammonium or hydrolysed by cell-surface enzyme(s) was not studied.

To assess the significance of urea decomposition in the mesopelagic $\mathrm{N}$ cycle, we calculated depthintegrated ammonium- $\mathrm{N}$ production caused by urea decomposition and compared it with sinking $\mathrm{N}$ flux from the euphotic zone and with new production. We calculated the $\mathrm{N}$ flux on the basis of the primary production according to the $\mathrm{N}$ flux model of Pace et al. (1987). New production was calculated according to Eppley \& Peterson (1979). The calculated $C$ flux was then converted into $\mathrm{N}$ flux by assuming a $\mathrm{C} / \mathrm{N}$ ratio of 7 by weight for the particles sinking out of euphotic zone (Table 1). The depth-integrated urea hydrolysis ranged from 10.3 to $44.5(21.1 \pm 16.1, \mathrm{n}=4) \mathrm{mg} \mathrm{N} \mathrm{m}^{-2}$ $\mathrm{d}^{-1}$ (Table 1). Our calculations showed that urea decomposition in the aphotic zone in our profiles was equivalent to a major fraction of particulate sinking $\mathrm{N}$ flux $(78 \pm 35 \%, \mathrm{n}=4)$ and of new production (41 \pm $20 \%, \mathrm{n}=4$; Table 1 ). The actual particulate- $\mathrm{N}$ flux channeled via urea might be substantially less than calculated here if some of the urea- $\mathrm{N}$ is derived from 'sinking' DON rather than particulate organic nitrogen (PON) (Toggweiler 1989).

We can treat the added ${ }^{14} \mathrm{C}$-urea as a tracer of ambient urea only if the ambient urea is urease-sensitive. Degens (1970) made the qualitative observation that some of the urea associated with suspended POM and in the sediment interstitial water was acid-resistant, presumably because it occurred as a hexagonal adduct of urea. We did not try to determine whether signifi- 
cant pools of condensed urea were present in our samples. The urea pools we measured were urease-sensitive by virtue of the method of assay (the urease method of McCarthy 1970). Recently, Therkildsen \& Lomstein (1994) showed that all chemically measurable urea (determined by the diacetylmonoxime urea method) was hydrolyzed within 5 min by adding urease to the sediment samples. We therefore think that the decomposition rates we measured were representative of the substantial ambient pools of urease-sensitive urea present in the water. If significant pools of condensed urea were also present, then we have actually underestimated the true rates.

Our finding of the significance of bacterial hydrolysis of urea is consistent with the emergent view that bacteria are a major metabolic component in the mesopelagic zone (Cho \& Azam 1988, Simon et al. 1992, Hoppe et al. 1993). If we assume a steady-state between urea production and decomposition in the mesopelagic zone, then our study suggests that, somehow, a substantial fraction (on the order of $50 \%$ ) of the sinking $N$ flux (PON plus DON) follows the pathway: sinking- $\mathrm{N} \rightarrow$ urea $\rightarrow$ ammonium. This also raises the question of the mechanisms and organisms responsible for large-scale urea production in the mesopelagic zone. Bacteria may play a role in urea production as well because they are known to account for the metabolism of a major fraction of the sinking organic matter (Cho \& Azam 1988). However, at present we do not know the relative significance of bacteria, protozoa and metazoa in urea production in the mesopelagic zone. Further, urea might adsorb to sinking particles in the euphotic zone and be released upon particle fragmentation at depth (Degens 1970). Thus, the organisms and mechanisms producing urea in the mesopelagic zone have yet to be discovered.

The mesopelagic $\mathrm{N}$ cycle reported here represents a fundamental departure from the current view of the nitrogen cycle (Proesser 1986) in the mesopelagic zone. If mesopelagic bacteria use urea as a significant $N$ source, this could provide insight into the dynamics of bacterial growth and its influence on depth-dissipation of carbon. Urea decomposition to ammonium could supply the $N$ demand of mesopelagic bacteria and also influence the regulation of nitrification and ultimately the supply of upwelled nitrate into the euphotic zone. Since substantial concentrations of urea $(>1 \mu \mathrm{M})$ are found in the mesopelagic zone of the global ocean (Remsen 1971, Turley 1985, Sapozhnikov \& Propp 1988), it is of interest whether rapid urea turnover, as found in the Bight, is a geographically widespread phenomenon. We suggest that urea decomposition in the mesopelagic zone, and the role of bacteria in this process, should be considered in models of pelagic $N$ cycling in the ocean.
Acknowledgements. This work was supported by NSF grants OCE 89-18015 and OCE92-19864 to F.A., which also supported the postdoctoral work of B.C.C. We thank Dr R. W Eppley for enabling us to join the cruises and for helpful discussion, Dr B. B. Ward for a culture of Nitrosococcus oceanus, Drs James T. Hollibaugh and I. Koike for insightful comments and the captains and the crews of RV 'New Horizon' and RV 'Sproul' for their excellent coorporation. We thank 3 anonymous reviewers for their constructive suggestions which improved the manuscript.

\section{LITERATURE CITED}

Cho BC (1988) Significance of bacteria in biogeochemical fluxes in the pelagic ocean. PhD thesis, University of California, San Diego

Cho BC, Azam F (1988) Major role of bacteria in biogeochemical fluxes in the ocean's interior. Nature 332:441-443

Degens ET (1970) Molecular nature of nitrogenous compounds in sea water and recent marine sediments. In: Hood DW (ed) Organic matter in natural waters. Mar Sci Inst Univ of Alaska, Occas Publ, No 1, p 77-106

Eppley RW, Peterson BJ (1979) Particulate organic matter flux and planktonic new production in the deep ocean. Nature 282:677-680

Eppley RW, Renger E, Venrick E, Mullin MM (1973) A study of plankton dynamics and nutrient cycling in the central gyre of the North Pacific Ocean. Limnol Oceanogr 18: $534-551$

Fowler SW, Knauer GA (1986) Role of large particles in the transport of elements and organic compounds through the oceanic water column. Prog Oceanogr 16:147-194

Grasshoff K (1976). Methods of seawater analysis. Verlag Chemie, Weinheim

Hansell DA, Goering JJ (1989) A method for estimating uptake and production rates for urea in seawater using $\left[{ }^{14} \mathrm{C}\right]$ urea and $\left[{ }^{15} \mathrm{~N}\right]$ urea. Can J Fish Aquat Sci 46: 198-202

Harrison WG, Head EJD, Conover RJ, Longhurst AR, Sameoto DD (1985) The distribution and metabolism of urea in the eastern Canadian Arctic. Deep Sea Res 32: $1-23$

Hobbie JE, Daley RJ, Jasper S (1977) Use of Nuclepore filters for counting bacteria by epifluorescence microscopy. Appl environ Microbiol 33: 1225-1228

Hoppe HG, Ducklow H, Karrasch B (1993) Evidence of dependency of bacterial growth on enzymatic hydrolysis of particulate organic matter in the mesopelagic ocean. Mar Ecol Prog Ser 93:277-283

Karl DM, Knauer GA, Martin JH, Ward BB (1984) Bacterial chemolithotrophy in association with sinking particles. Nature 309:54-56

Keil RG, Kirchman DL (1993) Dissolved combined amino acids: chemical form and utilization by marine bacteria. Limnol Oceanogr 38:1256-1270

McCarthy JJ (1970) A urease method for urea in seawater. Limnol Oceanogr 15:309-313

McCarthy JJ (1980) Nitrogen. In: Morris I (ed) The physiological ecology of phytoplankton. Blackwell, Oxford, p $191-233$

McCarthy JJ, Kamykowski D (1972) Urea and other nitrogenous nutrients in La Jolla Bay during February, March, and April 1970. Fish Bull US 70:1261-1274

McCarthy JJ, Whitledge TE (1972) Nitrogen excretion by anchovy (Engraulis mordax and E. ringens) and jack mackerel (Trachurus symmetricus). Fish Bull US 70: $395-401$ 
Mezykowski T (1982) Distribution of dissolved amino acids, dissolved saccharides and urea in the southern Drake Passage and the Bransfield Strait during BIOMASS-FIBEX, 1981. Polar Biol 3:171-182

Mitamura O, Saijo Y (1975) Decomposition of urea associated with photosynthesis of phytoplankton in coastal waters. Mar Biol 30:67-72

Nagata T, Watanabe Y (1990) Carbon- and nitrogen-tovolume ratios of bacterioplankton grown under different nutritional conditions. Appl environ Microbiol 56: 1303-1309

Pace ML, Knauer GA, Karl DM, Martin JH (1987) Primary production, new production and vertical flux in the eastern Pacific Ocean. Nature 325:803-804

Price NM, Cochlan WP, Harrison PJ (1985) Time course of uptake of inorganic and organic nitrogen by phytoplankton in the Strait of Georgia: comparison of frontal and stratified communities. Mar Ecol Prog Ser 27:39-53

Proesser JI (1986) Nitrification. Soc Gen Microbiol, IRL Press, Washington, DC

Remsen CC (1971) The distribution of urea in coastal and oceanic waters. Limnol Oceanogr 16:732-740

Remsen CC, Carpenter EJ, Schroeder BW (1974) The role of urea in marine microbial ecology, In: Colwell RR, Morita RY (eds) Effects of the ocean environment on microbial activities. Univ Park Press, Baltimore, MD, p 286-304

Sapozhnikov VV, Propp LM (1988) General pattern of the verticai distribution of urea in Antarctic waters. Biol Morya (Vladivostok) N1:60-63

This article was presented by G. Rheinheimer (Senior Editonal Advisor), Kiel, Germany
Savidge G, Johnston JP (1987) Urea degradation rates by size-fractionated plankton populations in a temperate estuary. Estuar coast Shelf Sci $24: 433-447$

Simon M, Welschmeyer NA, Kirchman DL (1992) Bacterial production and the sinking flux of particulate organic matter in the subarctic Pacific. Deep Sea Res 39:1997-2008

Strickland JDH, Parsons TR (1972) A practical handbook of seawater analysis. Bull Fish Res Bd Can 167

Taga N (1972) Occurrence of urea-decomposing bacteria in the neritic and oceanic waters of the northwest Pacific ocean. In: Sugawara K (ed) Proc 2nd CSK symposium. Saikon Publishing, Tokyo, p 341-351

Therkildsen MS, Lomstein BA (1994) Seasonal variation in sediment urea turnover in a shallow estuary. Mar Ecol Prog Ser 109:77-82

Toggweiler JR (1989) Is the downward dissolved organic matter (DOM) flux important in carbon transport? In: Berger WH, Smetacek VS, Wefer G (ed) Productivity of the ocean: present and past. John Wiley \& Sons, New York, p 65-83

Turley CM (1985) Biological studies in the vicinity of a shallow-sea tidal mixing front. IV. Seasonal and temporal distribution of urea and its uptake by phytoplankton. Phil Trans R SoC Lond B 310:471-500

Ward BB (1987) Nitrogen transformations in the Southern California Bight. Deep Sea Res 34:785-805

Williams PM (1986) Chemistry of dissolved and particulate phases in the water column. In: Eppley R (eds) Plankton dynamics of the Southern California Bignit. SpringerVerlag, Berlin, p 53-83

Manuscript first received: December 27, 1994

Revised version accepted: March 9, 1995 